\section{The Effect of Social Media Content on Buying Decision of HijUp.com}

\author{
Anggorowati Tyas $^{1}$, Olivia Hutagaol ${ }^{2}$ \\ 1,2 Institut Komunikasi dan Bisnis LSPR, Jakarta, Indonesia
}

\author{
Journal of Communication and Public Relations \\ Vol. 1, No. 1, December 2021, 32-40 \\ P-ISSN: XXXX-XXXX \\ E-ISSN: XXXX-XXXX \\ DOI: https://doi.org/10.37535/105001120214
}

\begin{abstract}
Social media is a channel to socialize with each other via online so that people can interact with each other without limited space and time. A variety of business sees many opportunities in the online media that can be used as a place to sell goods and services. Social media appears one of them is Facebook, Instagram, Twitter, YouTube and other social media. Hijup, a muslim fashion e-commerce, utilizes social media such as Instagram and Facebook to perform marketing strategies for its products. This study aims to determine the effect of social media content facebook and instagram on buying decision Hijup.com, to know the direction and influence of social media content facebook Hijup who play a role in buying decision at Hijup.com. The main theory used for this research is Elaboration Likelihood Model (ELM) to explain persuasion that sees every individual becomes very rational when evaluating persuasion messages, messages received differently for each individual then the impact will also be different. This research is using quantitative methodology with positivistic paradigm and explanatory of causality approach by using survei on 100 respondents. Hypothesis test results stated that there is a positive influence between social media content facebook and social media content Instagram simultaneously to the decision of purchase Hijup. There is a positive direction of influence on facebook social media content on purchasing decisions.
\end{abstract}

Keywords: social media; marketing; influence; buying decision

\title{
Introduction
}

As we know this time the technology development was supported by globalization and modernization. The usability and utilization of the technologies that are increasingly become the mainthing thing for human beings. Internet users in ASEAN currently has reached 3.773 billion per JANUARY 2017, if compared with the percentage of the community population is $50 \%$. We Are Social said, on JANUARY 2017 internet users in indonesia has reached 132.7 million users. If compared to 262 million residents in Indonesia, internet users has reached $51 \%$ of the total populations. This is the prove that internet has become part of the life of society in Indonesia, any information can be found on the internet. Internet is also used by a variety of activity ranging from active users of social media as a channel of online interaction. People who access the internet via mobile phones is $91 \%$ and access through laptops or PCs is $21 \%$. The use of mobile phones and internet users are high so social media get the impact and experience shifting function or revolution, which initially as media or platform for social 
interaction online now become media of promotion and existence of very wide economic market. Social media users in ASEAN according to We Are Social has reached 2,789 miliiar per JANUARY 2017, compared to the population in ASEAN is $37 \%$. In Indonesia, an active user of social media has reached 106 million per JANUARY 2017. A variety of business sees many opportunities in the online media that can be used as a place to sell goods and services. Social media appears one of them is Facebook, Instagram, Twitter, YouTube and other social media.

Social media is a channel to socialize with each other via online so that people can interact with each other without limited space and time. We Are Social explains if the use of social media facebook in ASEAN is take in first ranked while in Indonesia facebook was ranked 2 nd. Instagram usage in ASEAN is occupy in eight ranked and in Indonesia instagram was ranked third. In addition to shifting the function of social media, they was began to emerge ecommerce as a meeting platform between sellers and buyers. According to Chaffey (I Putu, 2015, p.2) after being refined in 2007 e-commerce is defined as any form of organizational and stakeholder information exchange process based on electronic media connected to the internet network. Various economic activities in the real world undergo many changes in innovation so that economic activity that happens to the world of the internet. Hijup.com is Muslim fashion e-commerce were discovered in 2011 that aims to facilitate community especially Muslim women to follow the trend (Hijup.com). Hijup was start to establishing a specialized and segmented market at the time, because Hijup saw the majority of Indonesia's population as $85 \%$ Muslim (Fitria S and Aini N, 2016). Hijup utilizes social media such as Instagram and Facebook to perform marketing strategies for its products.

Hijup not only sells its products to Indonesian citizens only, but also sells its products to all over the world. It can be seen from the options of the prices is available for 5 options: rupiah, ringgit Malaysia, Brunei dollar, the US dollar and Singapore dollar (Hijup.com). The hijup founder sees the Muslim population in Indonesia reaching 194.72 million could be a good market. In addition to the number of Muslim population in Indonesia, from the side of internet users and social media users, Indonesia is superior compared to Brunei Darussalam, Singapore and Malaysia. Based on We Are Social internet users and social media in Brunei Darussalam only reached 370 thousand per JANUARY 2017. Internet users and social media users in Malaysia has reached 22 million per JANUARY 2017. While in Singapore Internet users has reached 4.71 million and social media users is 4.40 million per JANUARY 2017. Based on what has been described in the background, the problem formulation that emerged in this research is there any influence of social media content facebook and instagram Hijup to buying decision on Hijup.com? This study aims to determine the effect of social media content facebook and instagram on buying decision Hijup.com, to know the direction and influence of social media content facebook Hijup who play a role in buying decision at Hijup.com, to know the direction and influence of social media content instagram Hijup that plays a role in buying decision at Hijup.com, to find out which factors are more influential on buying decisions at Hijup.com, whether the social media content facebook or instagram. The hypothesis in this study is social media content facebook and Instagram has no effect on buying decision Hijup, The absence of relation between facebook social media content to decision of buying Hijup, is there no relation between social media content instagram to decision of buying Hijup. Alternative hypothesis in the research is Social media content facebook and Instagram effect on purchasing decision Hijup.com, The relationship between facebook social media content to decision Hijup purchase, The relationship between social media content Instagram to purchase decision Hijup.com. 


\section{Literature Review}

The main theory used for this research is Elaboration Likelihood Model (ELM). Elaboration Likelihood Models based on the models of Richard Pettnol and John Cacioppo (in Kotler \& Keller, 2016, p.245) that influence change and attitude formation. This theory is a form of persuasion that sees every individual becomes very rational when evaluating persuasion messages, messages received differently for each individual then the impact will also be different. In Elaboration Likelihood Model theory illustrates the two routes found in this model, namely the central route and peripheral routes. The central route is the change and the formation of attitudes that occur because of the many thoughts and arguments based on good rational considerations of the most important information and product services, individuals who perform this route have the ability to process good messages. Peripheral route is change and attitude formation includes little thought and consequence association with positive or negative guidance, individual in this route do not see aspect of message content but aspect outside of content or just look at attraction of context. In this study using the central route because the message of persuasion or content contained in social media facebook and Instagram Hijup can be assessed in detail by using the thoughts and arguments of consumers so that it can produce a positive attitude change that is the purchase decision on Hijup.com. Content on social media facebook and instagram is included in the path of social proof for customers.

The facebook app was founded by Mark Zuckerberg with some of his friends at Harvard University, Eduardo Saverin, Andrew MacCollum, Dustin Moskovitz, and Chris Hughes on February 4, 2004 (Tim Pusat Humas Kementrian Perdagangan RI, 2014, p.72). Content in the form of photos, videos, and links on facebook (Parsons, 2011), each month is uploaded as much as 30 million content maintenance. According to Neher (2014, p.75) Instagram is a social media that allows users to upload or share editable photos and videos to be more interesting with various filters through smartphones. Content or persuasion messages contained in instagram are photos, hastags, and titles (Atiko, Sudrajat, \& Nasionalita, 2016). Miles $(2014$, p.23) instagram can help marketers because instagram is designed to do 1 thing that is uploading photos, because it has real power then it allows the marketer to influence the market.

According to Schiffman and Kanuk (2007, p.485) decision buying is when consumers are required to choose two or more alternatives. Once the consumer has determined what they want, it will occur to the purchase process. In other words, decision buying are actions taken by consumers in buying a product. In this study only use decision buying, because this study focuses on changes in attitudes that occur by consumers when making a purchase. Researchers can find out whether Hijup followers have ever made a purchase through a distributed questionnaire. The process before the purchase decision has been passed by the consumers or followers in this research. The introduction of the problem is when the consumers or followers are aware of the need to dress syar'l but still fashionable by following or following the facebook account and instagram Hijup. Search information conducted by consumers or followers is by searching \#myHIJUP through facebook or instagram, so that appear various kinds of testimonials and products owned by Hijup. Evaluate alternatives to consumers or followers when they have started liking or giving likes on facebook account or instagram. 


\section{Methods}

This research is using quantitative methodology with positivistic paradigm and explanatory of causality approach because it explains generalization of population samples that explain the influence and relationship between one variable with other variables. According to Hune, Locke, and Berkeley (Bungin, 2015, p.39) the paradigm is to emphasize the experience used as a source of knowledge that has the same relationship with views and philosophies known as positivism. This research, the population of facebook follower Hijup 278.154 and Instagram Hijup 553.292 on May 5, 2017, so that the researcher use sampling technique with simple random sampling 831.464 follower facebook and instagram Hijup done randomly. Researchers use simple random sampling because researchers want all respondents have the same opportunity. Samples taken are users who follow facebook and also instagram Hijup. Followers of facebook and Instagram summed up to get the exact sample amount. Respondents in this study as many as 100 people.

\section{Result and Discussion}

In this research has been tested the validity of the results of each statement is declared valid because the value of $r$ (corrected Item-Total Correlation) positive and greater than 0.3 . This study also tested the reliability, and the results of the statements are also realible because the value of cronbach's alpha is more than 0.6.

Table 1 Dimensional Analysis Photos of Facebook Hijup

\begin{tabular}{|c|c|c|c|}
\hline $\begin{array}{c}\text { Dimensio } \\
\mathrm{n}\end{array}$ & Indicator & Statement & $\begin{array}{c}\text { Frequenc } \\
y\end{array}$ \\
\hline \multirow{7}{*}{ Photo } & $\begin{array}{l}\text { Interesting } \\
\text { Photo }\end{array}$ & Facebook Hijup upload a good quality photos & 82 \\
\hline & & Photos on facebook Hijup are impressed & 79 \\
\hline & Photo & Hijup write a unique caption in every photo & \\
\hline & Caption & & 81 \\
\hline & & Hijup have a typical caption in every picture & 74 \\
\hline & Like Photo & You like every photo that Hijup upload on facebook & 80 \\
\hline & & $\begin{array}{l}\text { Many people are like the photos that uploaded by } \\
\text { facebook Hijup }\end{array}$ & 82 \\
\hline
\end{tabular}

In this dimension the indicator that has the highest value is an interesting photo and photo caption which the statements is facebook Hijup upload a good quality photo and many people are like the photos that uploaded by facebook Hijup has the highest value of 82 , so that Hijup need to pay attention to the quality of each uploaded photos. 
Table 2 Dimensional Analysis Video of Facebook Hijup

\begin{tabular}{|c|c|c|c|}
\hline $\begin{array}{c}\text { Dimensio } \\
\mathrm{n}\end{array}$ & Indicator & Statement & $\begin{array}{l}\text { Frequenc } \\
y\end{array}$ \\
\hline & $\begin{array}{l}\text { Interesting } \\
\text { Video }\end{array}$ & The videos featured in facebook Hijup quite interesting & 82 \\
\hline & & $\begin{array}{l}\text { Videos on facebook Hijup uploaded are various and not } \\
\text { boring }\end{array}$ & 81 \\
\hline & Benefit & Videos on facebook Hijup are given useful for your daily & \\
\hline \multirow[t]{5}{*}{ Video } & Video & life & 84 \\
\hline & & $\begin{array}{l}\text { Hijup upload videos that allow you to dress in a } \\
\text { muslimah way }\end{array}$ & 90 \\
\hline & Caption & Interesting caption makes you want to watch the video & \\
\hline & Video & & 80 \\
\hline & & The caption is corresponds with the content in the video & 84 \\
\hline
\end{tabular}

In this dimension the indicator that has the highest value is the benefits of video which the statement is Hijup upload videos that allow you to dress in a muslimah way has the largest percentage of $90 \%$, so this needs to be considered. Videos that facilitate the consumer is a video that contains tutorials in using clothes with fashionable way and makeup in accordance with the shape of each consumer body.

Table 3 Dimensional Analysis Link of Facebook Hijup

\begin{tabular}{|c|c|c|c|}
\hline $\begin{array}{l}\text { Dimensio } \\
\mathrm{n}\end{array}$ & Indicator & Statement & $\begin{array}{l}\text { Frequenc } \\
y\end{array}$ \\
\hline \multirow{6}{*}{ Link } & $\begin{array}{l}\text { Interesting } \\
\text { Information }\end{array}$ & $\begin{array}{l}\text { The information that contained on the link is } \\
\text { informative for you }\end{array}$ & 89 \\
\hline & & $\begin{array}{l}\text { The content or information that contained on the link } \\
\text { facebook Hijup is unique }\end{array}$ & 80 \\
\hline & Benefit of Link & The links in facebook Hijup help you & 87 \\
\hline & & $\begin{array}{l}\text { The information that is in the link in facebook Hijup } \\
\text { is useful }\end{array}$ & 83 \\
\hline & $\begin{array}{l}\text { Importance of } \\
\text { Link }\end{array}$ & Information on shared links is important & 82 \\
\hline & & Information that shared on links uptodate & 81 \\
\hline
\end{tabular}

In this dimension the indicator that has the highest value is interesting information which the statement is the information that contained on the link is informative for you have the highest percentage of $89 \%$, so it is need to be considered. The information that is usually in the intention in this research is articles that are distributed through facebook containing things related to women and Islam, such as one of the articles on how to bath properly according to Islam. 
Table 4 Dimensional Analysis Photo of Instagram Hijup

\begin{tabular}{|c|c|c|c|}
\hline Dimension & Indicator & Statement & $\begin{array}{l}\text { Frequenc } \\
\text { y }\end{array}$ \\
\hline \multirow{12}{*}{ Photo } & Interesting & Instagram Hijup has a good quality photo & \\
\hline & Photo & & 94 \\
\hline & & Photos of Instagram Hijup trendy and fashionable & 92 \\
\hline & Photo & Instagram Hijup upload a good quality photos with & \\
\hline & Consistent & consistently & 90 \\
\hline & & $\begin{array}{l}\text { Instagram Hijup always upload a photos that make } \\
\text { you interest }\end{array}$ & 89 \\
\hline & Like Photo & You like the photos in Instagram Hijup & 93 \\
\hline & & $\begin{array}{l}\text { Many people like the photos that are shared in } \\
\text { Instagram Hijup }\end{array}$ & 91 \\
\hline & Photo & You also comments on photos shared in Instagram & \\
\hline & Comment & Hijup & 71 \\
\hline & & Many people give a good comments on Instagram & \\
\hline & & Hijup photos & 81 \\
\hline
\end{tabular}

In this dimension the indicator that has the highest value is an interesting photo with the statement Instagram Hijup has a good quality photo because the percentage of the statement highest is $94 \%$. Good photo quality owned by Hijup is the resolution of the uploaded photo has a professional standard.

Table 5 Dimensional Analysis Hashtag of Instagram Hijup

\begin{tabular}{lllr}
\hline \multirow{2}{*}{ Dimension } & Indicator & Statement & \multicolumn{2}{c}{ Frequenc } \\
\hline \multirow{4}{*}{ Hastag } & $\begin{array}{l}\text { Interesting } \\
\text { Hastag }\end{array}$ & You know \#myHIJUP in every photo Instagram Hijup & y \\
\cline { 2 - 4 } & & \#myHIJUP has a unique meaning & 86 \\
\cline { 2 - 4 } & $\begin{array}{l}\text { Identic } \\
\text { Hastag }\end{array}$ & \#myHIJUP has become an identity for Hijup.com & 85 \\
\cline { 2 - 4 } & & & $\mathbf{9 1}$ \\
\hline
\end{tabular}

In this dimension the indicator that has the highest value is identic Hastag with the statement \#myHIJUP has become the identity for Hijup.com has the highest percentage of $91 \%$. Hastag \#myHIJUP is already attached and the identity for e-commerce Hijup. Hijup always use \#myHIJUP in every post uploaded 
Table 6 Dimension Analysis Caption of Instagram Hijup

\begin{tabular}{lllr}
\hline Dimension & Indicator & Statement & Frequency \\
\hline \multirow{5}{*}{ Caption } & $\begin{array}{l}\text { Interesting } \\
\text { Caption }\end{array}$ & $\begin{array}{l}\text { Title on the caption makes you want to buy the } \\
\text { product on that photo }\end{array}$ & 77 \\
\cline { 2 - 4 } & \multicolumn{2}{c}{ The caption on Instagram Hijup is interesting } & 86 \\
\cline { 2 - 4 } & $\begin{array}{l}\text { Photo } \\
\text { Informatio }\end{array}$ & $\begin{array}{l}\text { The caption is contained an information that helps } \\
\text { you know which products and prices are used }\end{array}$ & \\
\cline { 2 - 4 } & & $\begin{array}{l}\text { The information on caption is complete and } \\
\text { accordance with the photo }\end{array}$ & 87 \\
\hline
\end{tabular}

In this dimension the indicator that has the highest value is the photo information with the statement the information on caption is complete and accordance with the photo has the highest percentage of $94 \%$. As one example of Hijup provide complete and appropriate information is "Faida Outer from HIJUP X MAJA INDONESIA Rp399.000, - available in size $M, L \& X L$, Material used is Balotelli. For reservations please click bio link www. hijup.com/ig or contact our customer service via 021-7894001 / 80682226. Email customer@hijup.com and enjoy the convenience of shopping through HIJUP Official Line Account @hijup (using @) Happy shopping :)".

Table 7 Dimensional Analysis of Decision Buying

\begin{tabular}{|c|c|c|c|}
\hline Dimension & Indicator & Statement & $\begin{array}{l}\text { Frequenc } \\
y\end{array}$ \\
\hline \multirow{7}{*}{$\begin{array}{c}\text { Decision } \\
\text { Buying }\end{array}$} & Fulfillment & $\begin{array}{l}\text { Hijup.com helps you to meet the needs of } \\
\text { Muslimah clothing in a modern way }\end{array}$ & 95 \\
\hline & & $\begin{array}{l}\text { Hijup give the information needs of Muslim } \\
\text { fashion }\end{array}$ & 94 \\
\hline & & $\begin{array}{l}\text { All your fashion needs can be found through } \\
\text { Hijup.com }\end{array}$ & 88 \\
\hline & Make a & You've bought Muslim clothes through Hijup.com & \\
\hline & Purchase & & 79 \\
\hline & & You've bought shoes or accessories at Hijup.com & 69 \\
\hline & & $\begin{array}{l}\text { Content in social media facebook and instagram } \\
\text { Hijup makes you want to make a purchase }\end{array}$ & 87 \\
\hline
\end{tabular}

In this dimension the indicator that has the highest value is the fulfillment of needs with the statement Hijup.com help you in meeting the needs of Muslim clothing in modern way has the highest percentage of $95 \%$. The products owned by Hijup is fashionable but still in syar'l way. Distribution of the questionnaire in this study was stated normal because the value of skweness of social media content variable facebook is equal to -2.304 , social media content instagram variable has skewness value of -2.570 , and skewness value of variable y equal to -1.443. All skewness values of each variable close to 0 , which means that the data analysis in this study is distributed normally. The correlation in this study was stated positive and significant because the value of facebook social media content to the purchase decision of 0.714 and the correlation between the content of social media instagram to the purchase decision of 0.774 . Based on the data in though by the researchers there are $61.1 \%$ contribution variable $\mathrm{X} 1$ social media content facebook and $\mathrm{X} 2$ social media content Instagram to $\mathrm{Y}$ is the 
purchase decision. The rest of $38.9 \%$ is influenced by other factors such as youtube social media content and endorsement. Based on t test results the social media content facebook has a lower influence value when compared with social media content intagram. Age instagram users in accordance with the target market Hijup 20-35 years, so this can be one factor for instagram has a higher value. Visible on average facebook statement has the highest score only 90 that statement Hijup display video that allows you in dressing muslimah, whereas if seen from the grin statement on instagram the highest value is 94 in the statement instagram Hijup has good photo quality and information written is complete and in accordance with the picture.

Table 8 ANOVA Analysis

\begin{tabular}{l|l|r|r|r|r|r}
\hline \multicolumn{2}{l|}{ Model } & Sum of Squares & Df & Mean Square & $\mathrm{F}$ & Sig. \\
\hline \multirow{2}{*}{1} & Regression & 643.144 & 2 & 321.572 & 76.033 & $.000^{\mathrm{b}}$ \\
\cline { 2 - 7 } & Residual & 410.246 & 97 & 4.229 & & \\
\cline { 2 - 7 } & Total & 1053.390 & 99 & & & \\
\hline
\end{tabular}

a. Dependent Variabel: Keputusan Pembelian

b. Predictors: (Constant), X1, X2

Sig value in this research is 0.000 . Which means, the Sig value is smaller than 0.05 so $\mathrm{Ho}$ is rejected and $\mathrm{Ha}$ accepted. So the influence in the social media content facebook and social media content Instagram of the decision to purchase Hijup. In accordance with the theory used form of persuasion in the form of social media content facebook and social content instagram effect on changes or the formation of attitudes that become attitudes to make purchases.

\section{Conclusion}

The contribution of social media content of facebook content and social media content of instagram to explain variation of consumer purchase decision is $61,1 \%$. Hypothesis test results stated that there is a positive influence between social media content facebook and social media content Instagram simultaneously to the decision of purchase Hijup. There is a positive direction of influence on facebook social media content (X1) on purchasing decisions (Y). The magnitude of the effect of value (X1) is 0.071 if the social media content facebook (X1) increases one unit then the purchase decision (Y) will also increase by 0.071 and significant influence. The highest-rated statement is Hijup showing videos that make it easy for you to dress in a muslimah, so if Hijup adds a variety of videos that help the consumer then the purchase decision will increase. There is a positive direction of influence on the content of instagram (X2) social media on purchasing decisions $(Y)$. The magnitude of the effect of value $(\mathrm{X} 2)$ is 0.228 if the content of social media instagram (X2) has increased one unit then the purchase decision ( $\mathrm{Y}$ ) will also increase by 0.228 and significant influence. Statement that has the highest value is Hijup instagram has good photo quality and written information is complete and in accordance with the photograph, so if Hijup provide product detail information on the photos that have good quality then the decision will increase. It can be seen that the social media content of facebook has a lower value than the content of social media instagram, so instagram Hijup has a value and influence greater or higher and significant.

Based on the results of research on social media content facebook and social media content instagram on purchasing decisions, it shows that the contribution of social media content 
facebook and social media content instagram of $61.1 \%$, while the rest of $38.9 \%$ explained by other factors. Not used in this study, therefore it is expected for students, especially students majoring in communication who want to do more research on social media, especially social media facebook and social media instagram, better to investigate other factors of facebook and instagram that is not included in This research such as endorsements, geotagging, editors, cameras and social networking on instagram or boost on facebook are often done by other online stores.

\section{References}

Atiko, G., Sudrajat, R. H. \& Nasionalita, K. (2016). ANALISIS STRATEGI PROMOSI PARIWISATA MELALUI MEDIA SOSIAL OLEH KEMENTERIAN PARIWISATA RI (STUDI DESKRIPTIF PADA AKUN INSTAGRAM @INDTRAVEL). Retrieved from ejurnal:

file://C:/Users/a/Documents/Skripsi/Skripsi\%20Fix/Cek\%20Penulisan/Conten\%20Inst agram\%20Fix.pdf

Bungin, B. (2014). Metodologi Penelitian Kuantitatif Komunikasi, Ekonomi, Dan Kebijakan Publik Serta Ilmu-ilmu Lainnya. Jakarta: Kencana.

Fitria, S. \& Aini, N. (2016). Sontek Bangun Bisnis Mode Hijab Gaya Hijup.com. Retrieved from website: http://www.republika.co.id/berita/ekonomi/makro/16/05/25/o7qcnv382-sontekbangun-bisnis-mode-hijab-gaya-Hijupcom

Hijup.com (n.d). Tentang Kami. Retrieved from website: https://www.Hijup.com/id/pages/about

Inge, H. (2015). Teori-Teori Komunikasi dalam Pengaruh Sosiologi. Jakarta: PT Indeks.

I Putu, A. E. K. (2015). E-commerce, E-business dan Mobile Commerce Berbasiskan Open Sources. Bandung: Informatika.

Kotler, P. \& Keller, K. L. (2016). Manajemen Pemasaran: Edisi Kedua Belas Jilid 1. Jakarta: PT Indeks.

Miles, J. G. (2014). Instagram Power. America: McGraw- Hill Education.

Neher, K. (2014). Visual Sosial Marketing for Dummies a Wiley Brand. New Jersey: John Wiley \& Sons, Inc.

Parsons, A. L. (2011, Agustus). SOCIAL MEDIA FROM A CORPORATE PERSPECTIVE: A CONTENT ANALYSIS OF OFFICIAL FACEBOOK PAGES. Retrieved from e-jurnal: Academy of Marketing Studies volume 16 number2

Schiffman, L. \& Kanuk, L. L. (2007). Perilaku Konsumen: Edisi Ketujuh. Jakarta: PT Indeks.

Tim Pusat Humas Kementrian Perdagangan RI. (2014). Panduan Optimalisasi Media Sosial untuk Kementrian Perdagangan RI. Jakarta: Pusat Hubungan Masyarakat.

We Are Social (2017). Southeast Asia digital, social and mobile 2017. Retrieved from website https://aseanup.com/southeast-asia-digital-social-mobile/ 